Home Range and Habitat Use of Capybara in

THERYA, abril, 2014

Newly Invaded Pastureland in the Dry Chaco

Vol.5(1): 61-79

Region of Paraguay

DOI: 10.12933/therya-14-177

\title{
Rango de Hogar y uso de Hábitat de Carpinchos en Pastizales recién invadido en el Chaco Seco de Paraguay
}

Juan M. Campos-Krauer ${ }^{1 *}$, Samantha M. Wisely², Ivan K. Benitez', Victor Robles ${ }^{1}$ and Richard T. Golightly ${ }^{3}$

Introduction: Deforestation is one of the primary causes of species decline worldwide. Some species, however, can take advantage of change and expand their distribution, putting endemic species in danger of extinction, changing the composition of biotic communities, and altering ecosystems.

Methods: From June 2005 to July 2007, using radiotelemetry collars and implants we investigated home range, habitat use and body temperature dynamics of six capybaras (Hydrochoerus hydrochaeris). The study took place in a deforested area of the Central Dry Chaco region of Paraguay recently invaded by the species.

Results: The results show that the average home range of capybaras was 183 ha, similar to reported home ranges of capybaras in the Brazilian Pantanal. Within the study area, capybaras used and selected water significantly more than Chaco forest and pasture land, and had lower than expected use of shrub forest. Overall, capybaras were located $95 \%$ of the time $<500 \mathrm{~m}$ from permanent water, with the greatest distances from water occurring at 3:00 and 5:00 AM. Average year round body temperature was $36.15{ }^{\circ} \mathrm{C}$. There was a significant positive correlation between body temperature and distance from water, and a significant negative correlation between distance from water and Chaco ambient temperature.

Discussion: These findings suggest that capybaras use water to thermoregulate. The results show how anthropogenic habitat modification has allowed capybaras to thrive in a harsh xeric environment, and assists us in understanding how capybaras can expand into deforested areas. This study provides valuable information for the future management of the species in the Dry Chaco region of Paraguay.

Key words: Capybara, Chaco region, habitat use, home range, invasive species, thermoregulation.

\footnotetext{
PProyecto Taguá- Centro Chaqueño para la Conservación e Investigación. Fortín Toledo. Paraguay. E-mail: jmcampos@ cccipy.org (JMCK), ibenitez@cccipy.org (IKB), vrobles@cccipy.org (VR)

${ }^{2}$ Department of Wildlife Ecology and Conservation. University of Florida. Gainesville, Florida 32611, EE.UU. E-mail: wisely@ufl.edu (SMW)

${ }^{3}$ Department of Wildlife. Humboldt State University. Arcata, California, 95518, EE UU. (RTG)

*Corresponding author
} 
La deforestación es una de las principales causas de la desaparición de especies en todo el mundo. Algunas especies, sin embargo, pueden aprovechar los cambios y ampliar su distribución, poniendo a las especies endémicas en peligro de extinción, cambiando la composición de las comunidades bióticas y alterando los ecosistemas. Entre junio de 2005 y julio de 2007 se determinó el rango de hogar, el uso del hábitat y la temperatura corporal de seis carpinchos (Hydrochoerus hydrochaeris), a través de collares e implantes de radiotelemetría en una área deforestada de la región del Chaco Central del Paraguay invadida recientemente por carpinchos. Nuestros resultados muestran que el rango de hogar promedio de los carpinchos fue de 183 ha, similares a los descriptos en el Pantanal brasileño. Dentro del área de estudio los carpinchos utilizaban el agua significativamente más que su disponibilidad, seguido del bosque chaqueño y tierras de pastoreo, y utilizaban en un rango menor de lo esperado los malezales. En general, los carpinchos se encontraban el 95\% del tiempo a $<500 \mathrm{~m}$ de fuentes permanentes de agua, con las mayores distancias del agua a las 3:00 y las 5:00 hs. El promedio anual de la temperatura corporal fue de $36.15^{\circ} \mathrm{C}$. Se encontró una correlación positiva significativa entre la temperatura corporal y la distancia de la fuente de agua, y una correlación negativa significativa entre la distancia del agua y la temperatura ambiente del Chaco. Estos hallazgos sugieren que el carpincho efectivamente utiliza el agua para regular su temperatura. Nuestros resultados muestran cómo la modificación del hábitat por el hombre ha permitido al carpincho prosperar, y nos ayudan a entender cómo pudieron invadir y utilizar las áreas deforestadas. Este estudio proporciona información valiosa para el manejo futuro de la especie en la región del Chaco Seco de Paraguay.

Palabras clave: Carpincho, Chaco, especies invasoras, hábitat, rango de hogar, termorregulación.

Anthropogenic habitat destruction and land fragmentation are the main causes of biodiversity loss worldwide (National Research Council 2001; Fahrig 2003), followed by the introduction and expansion of exotic species placing endemic species at risk of extinction (Aguirre and Tabor 2008), changes in the composition of biotic communities, and altered ecosystem services (Vitousek et al. 1997; Lockwood et al. 2007). However, not only can exotic species benefit from land use change, native species can take advantage and expand into ecosystems where they historically did not occur. The expansion of native species has been driven by land use and land management changes such as agriculture, game exploitation, predator and poaching controls (Acevedo et al. 2006). For example, coyotes (Canis latrans) were historically restricted to central North America, but have expanded and colonized most of the North American continent in less than two centuries (Fener et al. 2005). Many more native species are known to have taken advantage of anthropogenic land modification and expanded their range (coypu, Guichón et al. 2003; Steven et al. 2004).

Capybara (Hydrochoerus hydrochaeris) is the world's largest living rodent with an average weight of $50 \mathrm{~kg}$ (Mones and Ojasti 1986; Nowak 1991). They are semi-aquatic 
mammals, extensively distributed throughout most of South America, from Colombia south into central Argentina, Paraguay and Uruguay (Redford et al. 1990; Ojasti and Robinson 1991). Capybaras inhabit open flooded grasslands as well as densely vegetated areas around permanent water sources such as ponds, rivers, marshes, and swamps.

Although closely associated with aquatic environments, capybaras use water primarily as a place of refuge, and most normal activity is on land (Schaller 1976). Nevertheless, year-round water is essential for capybaras to be present in an area. Capybaras live in herds ranging from a pair to complex groups of several adults of both sexes and their offspring (Azcarate 1980; Schaller and Crawshaw 1981; Mones and Ojasti 1986; Herrera 1992). These giant rodents are efficient grazing herbivores, feeding primarily on aquatic plants and grasses that grow in or near water (Gonzalez and Parra 1972; Macdonald 1981; Lord and Lord 1988; Quintana and Malvarez 1994, 1998; Barreto and Herrera 1998). Capybaras have been documented to share grazing areas with livestock and it is not uncommon for populations of capybaras to benefit from pasture management, predator control and provisioning of water by ranchers (Mones and Ojasti 1986; Ojasti and Robinson 1991; Quintana 2003). In certain regions of Brazil, capybaras have become an agricultural pest due to changes in habitat as a result of ranching and agriculture (Paschoaletto et al. 2003).

Capybara ecology, home range and habitat use have been previously studied throughout the core of their distribution, in habitats such as tropical forest and seasonally flooded plains where the species is locally abundant (Cordero and Ojasti 1977, 1981; Alho et al. 1987; Herrera and Macdonald 1989; Lord 1991; Herrera 1992; Quintana and Malvarez 1994; Barreto and Herrera 1998; Quintana 2002, 2003). By contrast, our study area is in the central Gran Chaco ecosystem of Paraguay at the periphery of its historical distribution. Recent deforestation in this region has facilitated the expansion of this species from more mesic habitat into the central Chaco (Campos-Krauer and Wisely 2011), where populations densities are low (Brooks 1998).

The central Chaco is dominated by thick tropical xeric thorn forest characterized by the trees Quebracho Blanco (Aspidosperma quebracho-blanco) and Guaimipire (Ruprechtia triflora), cacti and bromeliads (Holdridge 1969; Gorham 1973; Bucher 1982; Redford et al. 1990; Glatzle 1999; Mereles 2013). It experiences large variations in temperature between summer and winter with temperature during the summer reaching highs of 47 ${ }^{\circ} \mathrm{C}$, and below freezing during winter; with an annual mean temperature of $24{ }^{\circ} \mathrm{C}$ to $25.5{ }^{\circ} \mathrm{C}$ (Savaria-Toledo 1993). Annual precipitation ranges between 600 and $1000 \mathrm{~mm}$ y (Gorham 1973, Adámoli et al. 1990). As much as $80 \%$ of the annual precipitation occurs from November to May (Eidt 1968). Precipitation and standing water diminish greatly or even disappear completely during the colder dry season that extends from June to October (Hueck 1966; Gorham 1973)

Due to these harsh characteristics of the Paraguayan Chaco ecosystem, it has remained mostly undeveloped and immune to modern anthropogenic land modification until recent years. The rate of deforestation has dramatically increased since the $1970 \mathrm{~s}$ (Benirschke et al. 1989). Currently, approximately 1,000 ha of native forest are cleared daily and transformed into pastureland, with an estimated 3.5 M hectares cleared in the last decade (Huang et al. 2009; Caldas et al. 2013). To support a growing cattle population, approximately one pond is constructed for every 100 ha of pasture to 
maintain year-round water. The conversion of dense xeric thorn forest to pasturelands and the availability of year-round water supply have greatly altered the resource potential of the ecosystem.

The Chaco region is an area in which capybaras have been present for thousands of years. However, much of the best habitat for capybaras is located in the southern Humid Chaco region along the shorelines of rivers and in marshes. It is clear that capybaras are taking advantage of land use change to expand their range to the central Chaco region (Campos-Krauer and Wisely 2011). Understanding the factors and mechanisms that have allowed this expansion requires a detailed understanding of how capybaras colonize areas on a fine scale. To this end, we examined movement patterns, habitat use, and thermal ecology in several groups of capybaras in the central Chaco region to better understand the ecological drivers of the species' range expansion. In this paper, we describe and compare home range and habitat use of capybaras in the Chaco and compare our results with observations in other studied regions. This information will be valuable to forecasting future distributions and vulnerabilities in light of human activities.

Material and Methods

Study area. The research was carried out from June 2005 to October 2007, at Fortín Toledo, Boquerón Dept., Paraguay $\left(-22^{\circ} 21^{\prime} 05^{\prime \prime} \mathrm{N},-60^{\circ} 19^{\prime} 35^{\prime \prime} \mathrm{W}\right.$; Fig. 1). The study was carried out in and around a biological reserve of approximately 180 ha surrounded by private ranches which add up to a total area of 3,500 ha. Land cover in the study area consisted primarily of open water plus four vegetation types: 1) Chaco forest is virgin tropical xeric thorn forest characterized by thick understory vegetation with an abundance of bromeliads (Bromelia spp. and Dyckia spp.). Trees are less than $15 \mathrm{~m}$ tall with many spines, dominated by tree species such as quebracho (Schinopsis quebracho-colorado), bottle tree (Chorisia insignis), palo santo (Bulnesia sarmientoi), mistol (Zizyphus mistol) and verde olivo (Cercidium praecox). This habitat is distributed across the landscape as remnant forest islands surrounded by pasture or secondary growth. 2) Shrub Chaco forest consists of secondary forest regrown from 25 year-old, introduced pastures. This habitat is characterized by a wide variety of thorny shrubs, dominated by Mimosa spp., Acacia spp. Prosopis alba, and P. nigra. Cacti are also diverse and abundant, with taxa such as Opuntia, Cleistocactus and several tree cacti such as Cereus spp. Within this habitat there is little to no understory vegetation, due mostly to soil compaction. 3) Exotic pasture is cleared forest characterized by non-native grasses dominated by gatton panic (Panicum maximum) and to a lesser extent star grass (Cynodon dactylon). These areas have few trees remaining and are divided into large paddocks in which cattle are maintained year-round with a water source. 4) Seasonally flooded grassy areas, small wetlands which occur as natural depressions, which will hold water during the rainy season, but dry out during the dry season. These areas have a mix of introduced and native grass species (Cynodon spp.) together with palm trees (Copernicia alba). In addition to natural wetlands, areas surrounding man-made ponds had a high abundance of grass.

Areas of open water from man-made ponds were present in each pasture paddock in the study area. Each reservoir was at least $625 \mathrm{~m}^{2}$ and $1.5 \mathrm{~m}$ in depth and many were covered by aquatic plants such as Eichhornia crassipes and Pistia stratiotes. Ponds were 
generally built without modifying the surrounding forest, which was left to prevent eolic sand deposits and to provide shade for cattle. These forest patches and ponds remained as islands most of the time surrounded by pasture. During the dry season, standing water was found only in these man made ponds.

Figure 1. In the insert, the red dot indicates our study area, located in the central Dry Chaco region of Paraguay. Background color represents habitat types, as indicated. Colored lines represent overall 95 and 50\% Kernels for six capybara; each color represents an individual; black for capybara $1 \hat{\sigma}$, orange for $2 \mathrm{O}$, red for $45 \hat{\sigma}$, blue for 41 , pink for 43 ふand yellow for 50 오.

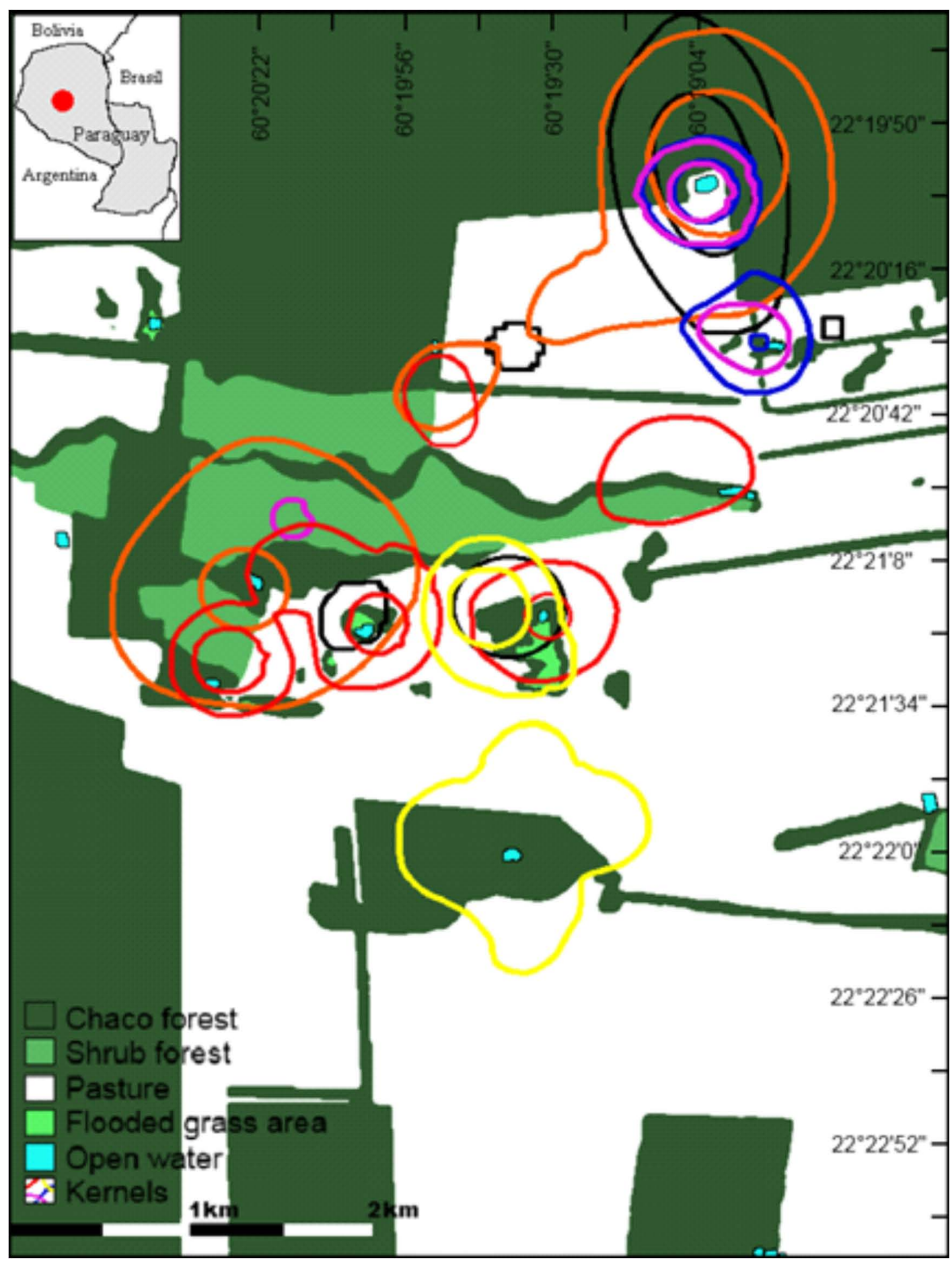

Capture and radiotelemetry. From June 2005 to August 2007, we located and monitored a total of 6 capybaras during different lengths of time (Table 1). Radio collars (Telonics, Inc., Mesa, Arizona 85202, USA) were placed on four capybaras (2 adult males, 2 adult 
females) and intra-abdominal implants with temperature sensors (Telonics, Inc) were placed in two capybaras ( 1 adult male and 1 juvenile male). The small sample size reflects the low density and difficulty of capture of capybaras in this study area and is representative of the patchily distributed populations within this region.

Animals were trapped with box-style live traps and chemically immobilized using a combination of Ketamine $\mathrm{HCl}$ (Ketalar, $4.7 \mathrm{mg} / \mathrm{kg}$ ), and Tiletamine $\mathrm{HCl} /$ Zolazepam $\mathrm{HCl}$ (Telazole, 1.17 mg/kg; Kreeger et al. 2002). Drugs were delivered intramuscularly by a blowgun (Telinject, U.S.A., Inc., Agua Dulce, CA) using 3 cc plastic darts (Telinject) or a standard 3 cc pole syringe. Animals were considered fully immobilized when they did not respond to external stimulus. Each animal was sexed, weighed and marked with eartags. All captured animals received a general examination to evaluate body condition, external parasites and possible wounds. Individuals were classified as juvenile (less than one year old) if $<25 \mathrm{~kg}$, and animals $>25 \mathrm{~kg}$ were considered to be at least one year old, and classified as young adults or adults (Ojasti 1971). Each transmitter was equipped with a mortality sensor which activated when animals had not moved for $>6$ hours. All procedures were in compliance with the Sectretaría del Ambiente, Paraguay; Kansas State University Institutional Animal Care and Use Committee (Protocol No. 2362); and guidelines approved by the American Society of Mammalogists (Gannon et al. 2007).

Independent telemetry locations (White and Garrott 1990) were estimated using triangulation with a minimum of three vectors per location. We marked and georeferenced $>50$ fixed reference locations every $500 \mathrm{~m}$ in the study area from which a vector bearing was collected. Vehicles were used to move between reference locations to reduce triangulation time. Three element folding yagi antenna (Advanced Telemetry Systems, Inc., Isanti, Minnesota), attached to a $3 \mathrm{~m}$ long aluminum pipe were used to maximize signal reception. Locations were estimated using a minimum of three vectors by using the maximum likelihood estimation option (Lenth 1981) in program LOAS (LOAS ${ }^{\text {тм }}$ 2005, Ecological Software Solutions LLC). We calculated an average location error from reference collars placed in random locations approximately $1 \mathrm{~m}$ from the ground. Animals were located at six hour intervals with the location time moving ahead one hour daily to cover a 24 hour period every 12 days. Readings were taken from capture until the animal was no longer located or died (Table 1).

Observers were able to detect animal movement due to differences in signal strength during data collection at a single vector. We recorded movement patterns from two capybaras (capy 41 and 43) with internal implants using this approach. Direct observations ( $n=193)$ and patterns of signal reception other than a consistent pulse intensity were considered to be an moving animal. These data reflected the time of day during which animals were moving. Movement patterns were analyzed as the number of individuals active per hour of day over the total number of locations for each hour of the day.

Home range analysis. We determined individual home range size using 95\%, 75\% and $50 \%$ fixed Kernel home ranges (Worton 1989), using the Animal Movement Analysis extension to ArcView, version 3.2 (ESRI, Environmental Systems Research Institute, Table 2). All animals had $>70$ locations and a minimum of two months of data (Table 1); however, of six animals, only three survived or retained their radio tag covering a period 
of time that included parts or the total wet and dry season, allowing us to estimate wet and dry season home ranges. We compared average home range size during the wet and dry season and compared the average of our home range estimates to other published estimates of home range for capybaras using a Student's $t$-test (Zar 1996). We calculated the distance from the estimated location to the nearest permanent water source using ArcView.

\begin{tabular}{|c|c|c|c|c|c|c|c|c|c|}
\hline \multirow{4}{*}{$\begin{array}{l}\text { Table 1. First column: } \\
\text { name of capybara } \\
\text { trapped, column } 1 \text { and } \\
2 \text { period of time during } \\
\text { which it was monitored, } \\
3 \text { sex, } 4 \text { weight, } 5 \text { group } \\
\text { to which it belonged, } 6 \\
\text { transmitter type, } 7 \text { total } \\
\text { location points, } 8 \text { final } \\
\text { report of the animal. }\end{array}$} & Name & 1 & 2 & 3 & 4 & 5 & 6 & 7 & \\
\hline & capy 1 & 07/03/2005 & 14/10/2005 & Male & 82 kg & 1 & Collar & 71 & Collar destroyed \\
\hline & capy 2 & $21 / 09 / 2005$ & $13 / 12 / 2005$ & Female & 56 kg & 1 & Collar & 185 & Disappeared \\
\hline & capy 45 & 03/02/2006 & 09/08/2006 & Male & $52 \mathrm{~kg}$ & 3 & Collar & 405 & Disappeared \\
\hline & capy 43 & $06 / 02 / 2006$ & $28 / 2 / 2007$ & Male & $17 \mathrm{~kg}$ & 2 & Implant & 435 & Disappeared \\
\hline & capy 41 & 28/06/2006 & 10/10/2007 & Male & $64 \mathrm{~kg}$ & 2 & Implant & 600 & Killed by puma \\
\hline & capy 50 & 06/10/2007 & 28/8/2007 & Female & 56 kg & 3 & Collar & 85 & Disappeared \\
\hline
\end{tabular}

Habitat use analysis. We compared utilized to available habitat to determine which habitats were preferred or avoided. Habitat types were identified and delimited from high resolution satellite images (eMap International, Boulder Colorado, USA). We created polygon shape files by hand corresponding to the 5 land cover types by using Geographic Information System (GIS). We delimited the study area as a $5 \times 7 \mathrm{~km}$ rectangle (3,500 ha) which incorporated the six minimum convex polygon (MCP) home range estimations (Mohr 1947) of our six study animals (Fig. 1). We carried out a compositional analysis to identify proportion of utilized and available habitat types, and evaluated whether they were used significantly more or less than expected by chance at two scales of use (Aebischer et al. 1993). First, we compared the proportion of habitat in the study area (the available habitat) with the proportion of habitat in each MCP home range (the used habitat). Second, we carried out a finer scale analysis by comparing the estimated proportion of habitat found in each MCP home range (the available habitat) to the proportions of observed animal locations within each habitat type (the used habitat) using ArcView, version 3.2 (Environmental Systems Research Institute). When no locations were recorded in a particular habitat type, a value of $0.01 \%$ replaced the zero as suggested by Aebischer et al. (1993).

To test the null hypothesis of random use, we calculated the difference in log-ratios between matching pairs of used and available habitats. This hypothesis was tested by a multivariate analysis of variance (MANOVA). If the hypothesis of random use was rejected, we then ranked the habitat types in order of relative use. For this analysis, we calculated the mean log-ratio difference for all possible pairs of habitat types, and compared them to zero using a t-test (Aebischer et al. 1993). Compositional analysis makes it possible to rank habitat types in order of relative use, although in our case, seasonal (dry and wet) sample sizes were too small to produce clear patterns of significant differences between ranks. Statistical tests were carried out with program SAS 9.1 (SAS Institute, Inc., Cary, North Carolina). 
Body temperature analysis. Two capybaras received internal radio-implants with temperature sensitive pulse rates. The temperature sensor monitored body temperature in the proximity of the implant. Special circuitry provided approximately $0.1^{\circ} \mathrm{C}$ resolution; a self calibration pulse interval eliminated calibration drifts due to aging and battery voltage changes over time. Transmitters were calibrated at the factory and retested at the field station to maximize accuracy. Temperature data were recorded as the number of pulses per minute. We also collected ambient temperature, humidity and wind direction for each triangulation animal for the two animals with implants. We assessed the relationship of body temperature with distance from water, ambient temperature, time of day and season using a multivariate analysis of variance (MANOVA) and conducting posterior univariate linear regressions implemented by program JMP-IN 4.0.4 (SAS 2001, SAS Institute Inc., Cary, North Carolina).

Results

Home range analysis. Over the study period we collected total of 1,781 locations with a minimum of 71 and a maximum of 600 locations per animal; with an estimated mean location error rate of $(41 \pm 12 \mathrm{~m}, n=9$; Table 2$)$. We found that there were patterns of spatial overlapping among individual capybara location points, between capybaras 95\% kernel home range (Table 3 ). We were only able to estimate temporal overlap among four capybaras. We found $82 \%$ temporal and similar spatial overlap between capybaras 43 and 41 demonstrating that they were in the same group. We found zero temporal overlap between capybaras 43 and 41 with capybaras 50 and 45 . Thus, we infer that capybaras 50 and 45 were from a separate group. Between capybaras 50 and 45, we were not able to estimate temporal overlap because they were radiomarked at different times during the study; however, we did find a spatial overlap of $19 \%$ and $80 \%$, which suggests that these animals were likely from the same group. Similarly, we were not able to estimate temporal overlap between capybaras 1 and 2, because contact with them was lost before other animals were radiomarked.

Based on our spatial and temporal overlap data and confirmed by direct observation we were able to confirm that two capybaras (43 and 41) were in the same group. From observational data we found the group was formed by one adult male (41), one untagged adult female, and four juveniles including 43. We found that capybaras 1 (adult male) and 2 (adult female) had a high percent of spatial overlap between them, as did capybaras 43 and 41 . These data suggest that capybaras 1 and 2 were possibly part of the same group, but that they either dispersed, or were depredated. We further infer that their home range was reoccupied by the group dominated by capybara 41. On the other hand, capybara 45 (adult male) had little overlap with any other capybara during the tracking period. This male was observed most of the time alone. However, on a few occasions it was observed together with a second capybara but with no juveniles. Home range analysis indicated that he was not part of the previously described group. This animal disappeared before capybara 50 (adult female) was trapped, which made it impossible to corroborate any temporal overlap between them. However, these animals had high spatial overlap, which suggests that this female may have been the one observed with capybara 45. 
In general, the great majority of capybaras were observed ( $n=304$ direct observations) near or on the shore of permanent ponds singly or in small groups, up to a maximum of six animals 2.4 ( \pm SD 1.4, $n=304)$. Capybaras were often observed resting in the shade or walking near the ponds. Activity patterns of two capybaras revealed that daytime activity was higher than at night, with peaks of activity at 16:00 and 20:00 hrs (Fig. 2).

Figure 2. Long-term mean percentage activity by time of day for capybaras 41 and 43 individually and pooled in the Central Dry Chaco region (based on $n=1035$ locations)

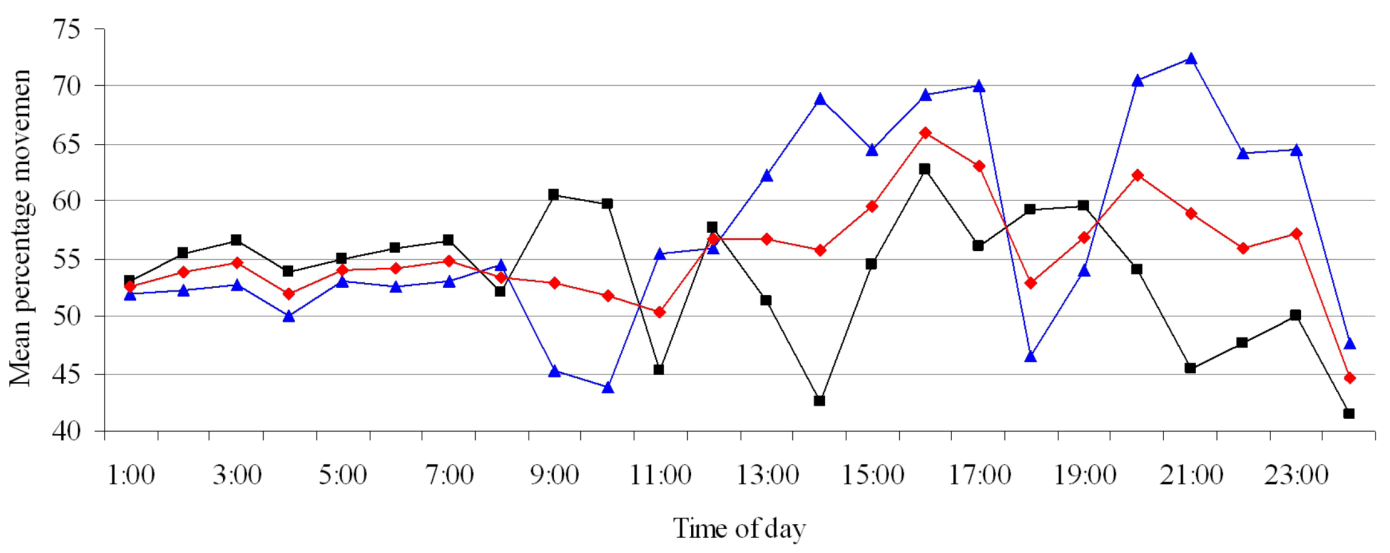

Using measures of adaptive kernels, the average 95\% kernel home range size was 183 ( \pm SD 54 ha, $n=6$ ), the $75 \%$ kernel $=64 \mathrm{ha}, \pm$ SD 22 ha, and the 50\% kernel $=28 \pm$ SD 9 ha (Table 2). We found no significant difference in home range size between seasons. Across seasons, the mean distance from water for all capybaras was 126 ( \pm SD $4 \mathrm{~m}, n=$ $1,781)$, with the distance from water increasing from 1:00 to $6: 00 \mathrm{AM}(\mathrm{t}=2.01, P<0.01$; mean $1=214$, Mean $2=132$ (Fig 3). We found that $95 \%$ of the locations were $<500$ $\mathrm{m}$ from a permanent water source, $84 \%$ were $<250 \mathrm{~m}, 64 \%$ were $<100 \mathrm{~m}$ and $46 \%$ were $<50 \mathrm{~m}$ from water.

Table 2. Overall capybara home range estimates.

\begin{tabular}{lllll}
\hline Name & MCP & $95 \%$ Kernel & $75 \%$ Kernel & $50 \%$ Kernel \\
\hline capy 1 & 437 & 193 & 75 & 42 \\
capy 2 & 492 & 421 & 168 & 67 \\
capy 45 & 737 & 198 & 58 & 24 \\
capy 43 & 484 & 52 & 17 & 10 \\
capy 41 & 997 & 62 & 27 & 10 \\
capy 50 & 352 & 176 & 40 & 16 \\
\hline Mean & 583 ha & 183 ha & 64 ha & 28 ha \\
\hline
\end{tabular}

Habitat use analysis. The average MCP home range size for all capybaras was $583( \pm$ SD 97 ha, $n=6$ ). Using our five land cover classifications (Chaco forest, shrub Chaco forest, introduced pasture, seasonally flood wetland and open water), we compared habitat use at two scales: the overall study area and within the MCP home range. Our results suggest that capybara did not establish home ranges at random $\left(\Lambda=0.023, \chi^{22}=74.16, P<0.0001\right)$. We assigned a ranking of a maximum of 4 for the habitat that was used most significantly and a minimum of 0 for the habitat that was significantly least used (Table 4). At the study 
area scale habitat types were used in the following hierarchal sequence; Chaco forest $>$ introduced pasture $>$ seasonally flood wetland $>$ open water $>$ shrub Chaco forest (Table 4A). Shrub Chaco forest was used significantly less than available, followed by water and flooded grass area which were used significantly less in proportion to their availability. It is important to clarify that water surface and flooded grass area made up a comparatively small proportion of the overall study area. The two highest-ranked habitats, Chaco forest and introduced pasture, were used significantly more than their availability within the study area, and Chaco forest was selected over pasture. On the smaller scale of home range, overall use of the five habitat types based on proportion of radio locations in each habitat type differed significantly from the proportion of habitat available within the MCP home ranges $\left(\boldsymbol{\Lambda}=0.037, \mathrm{x}^{2} 2=44.31, P<0.0001\right)$. The ranking matrix indicated that the following habitat type followed sequence; open water $>$ Chaco forest $>$ pasture $>$ flooded grass area $>$ shrub forest (Table 4B). Within the home range, water was the most highly preferred habitat. Chaco forest and pasture had no detectable difference in use from availability. On the other hand, flooded grass area was significantly less used than available and finally; shrub forest was used less than its availability, suggesting that capybaras were avoiding this habitat type.

Study long distance from water

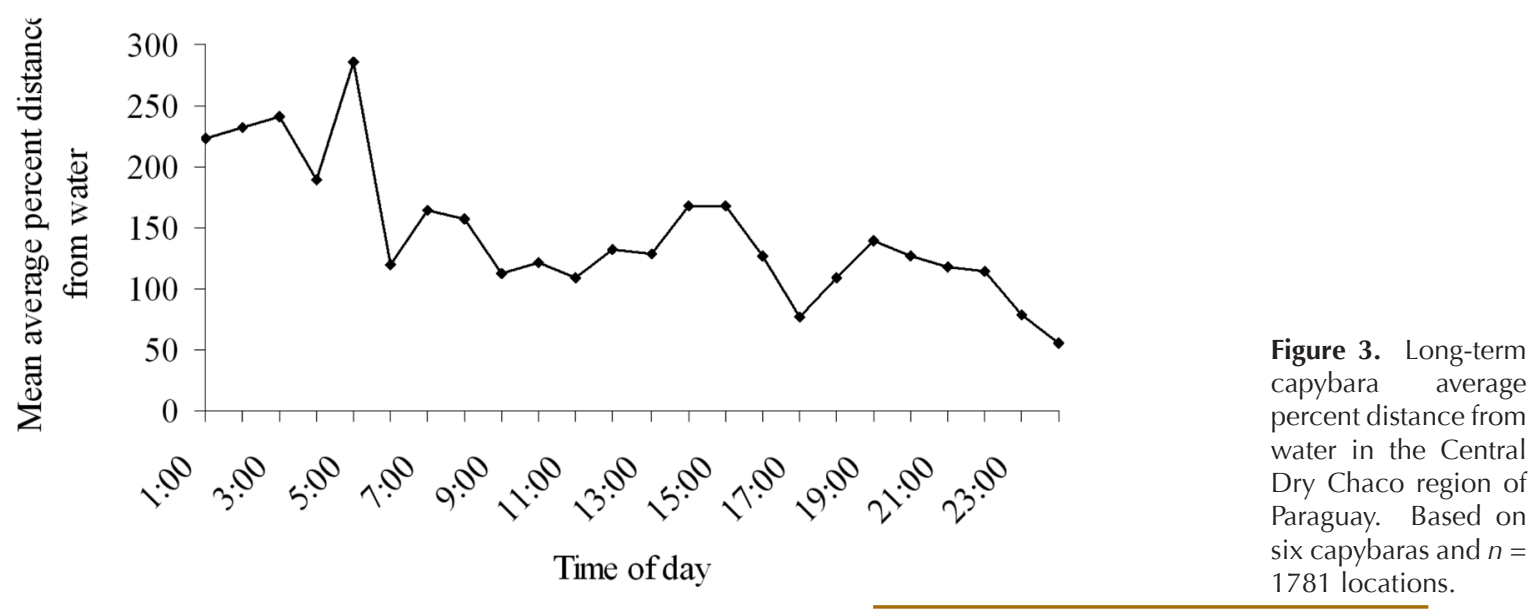

Body temperature analysis. The mean ambient temperature during the study was $28^{\circ} \mathrm{C}$, with an average day time temperature during dry season of $27.26{ }^{\circ} \mathrm{C}\left( \pm \mathrm{SD} 7.04{ }^{\circ} \mathrm{C}\right.$, $n=359)$ and night $24.64{ }^{\circ} \mathrm{C}\left( \pm \mathrm{SD} 5.66{ }^{\circ} \mathrm{C}, n=173\right)$. The mean daytime wet season temperature was of $31.88{ }^{\circ} \mathrm{C}\left( \pm \mathrm{SD} 6.10{ }^{\circ} \mathrm{C}, n=316\right)$ and night $29.52^{\circ}\left( \pm \mathrm{SD} 4.50{ }^{\circ} \mathrm{C}\right.$, $n=165)$. We found no significant difference between wet and dry day time ambient temperatures ( $P=1.96$; DF 673).

The mean body temperature for capybaras was $36.15^{\circ} \mathrm{C}\left( \pm \mathrm{SD} 0.27{ }^{\circ} \mathrm{C}, n=1021\right)$, with no significant difference between dry and wet season. We found a significant positive correlation between body temperature and distance of the animal from water $\left(r^{2}=0.004, P=0.02 ; F=4.51, D F=1008\right)$. Likewise, we found significant negative correlation between ambient temperature and distance in which the animal was located from water $\left(r^{2}=0.02, P<0.0001 ; F=29.01\right.$, DF = 1017; Fig. 4). 


\section{Discussion}

The study was conducted in a newly invaded area in which capybara population densities were low, thus our sample size was representative of the population at the leading edge of this newly occupied area (Brooks 1998; Campos-Krauer and Wisely 2009). Based on our direct observations and overlapping home range data, we confirmed that we were observing three groups of capybara. All groups were small, ranging from a pair to a family group of six. Each group had two to three ponds within their home ranges, near which they remained the majority of the time. Individuals within a group moved together to feed, rest or hide in surrounding habitats and always maintained the pond as the focal point. We found some spatial overlap but little temporal overlap between individuals from different groups. The exception was capybara two (female) who had high spatial overlap with two groups, and made occasional short solo trips to a neighboring pond.

\footnotetext{
Table 3. Asymmetrical matrix of percent data point spatial overlap between six capybaras monitored in the study area; columns correspond to percent overlap of corresponding capybara with different capybara.
}

\begin{tabular}{lcccccc}
\hline & capy 1 & capy 2 & capy 45 & capy 43 & capy 41 & capy 50 \\
\hline capy 1 & & 66 & 1 & 49 & 49 & 6 \\
capy 2 & 56 & & 20 & 29 & 29 & 0 \\
capy 45 & 38 & 79 & & 0 & 0 & 19 \\
capy 43 & 83 & 90 & 12 & & 84 & 1 \\
capy 41 & 78 & 94 & 9 & 86 & & 2 \\
capy 50 & 0 & 1 & 80 & 0 & 0 & \\
\hline
\end{tabular}

Activity patterns were similar to those of other populations in Venezuela (Herrera and Macdonald 1989) and Brazil (Alho et al. 1987). We found the highest activity of capybaras during the crepuscular hours with little movement during the middle of the day or at night. During the height of their movement, distance from water was less than $150 \mathrm{~m}$ indicating that movement was mostly in habitat directly surrounding or in ponds (Fig. 3). On the other hand, movement activity diminished during the night and distance from water increased. Groups moved during late afternoon and early night away from water ponds, occasionally moving to a different water pond or more commonly to a bedding area in the dense Chaco forest where they would spend the night. It appears that capybaras are using the cover of the darkness and the dense Chaco forest as protection during the night, moving closer to water the next morning (Fig. 3).

Capybara populations in the study area were not intensely persecuted by humans; occasional poaching was possible but rare. However, capybaras remained cautious of humans and as soon as human presence was detected, they would silently move toward the nearest ponds. Only when an animal was surprised by a human or a predator would they loudly jump in the water. Interestingly, capybaras remained in the water only for a few minutes where they would hide under aquatic vegetation. Shortly after entering the water, they would emerge and escape into the dense Chaco forest using it as the final hiding spot. 
Predators such as jaguar (Panthera onca) and puma (Puma concolor) were common in the region and study area. One radiocollared capybara was confirmed to have been killed by a puma at the shore of a pond. Tracks and signs of predators were not uncommon surrounding the ponds. Similarly, the great majority of ponds in the study area had caiman (Caiman yacare) that are known to depredate juvenile and subadult capybara (Lord 2009). Their presence and the small size of some of the ponds in our study area could explain why capybaras tended to bed down in forested areas during the night, and use water as an escape mechanism for only a short while.

A. Ambient temperature vs capybara distance from water

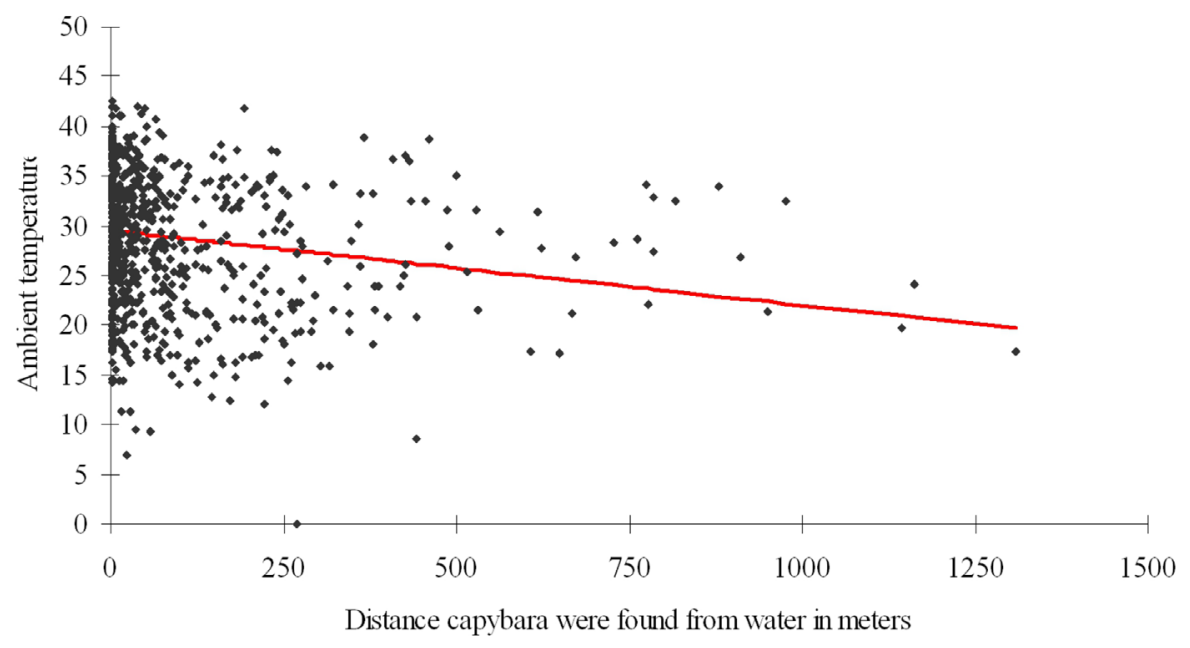

B. Capybara body temperature vs distance from water

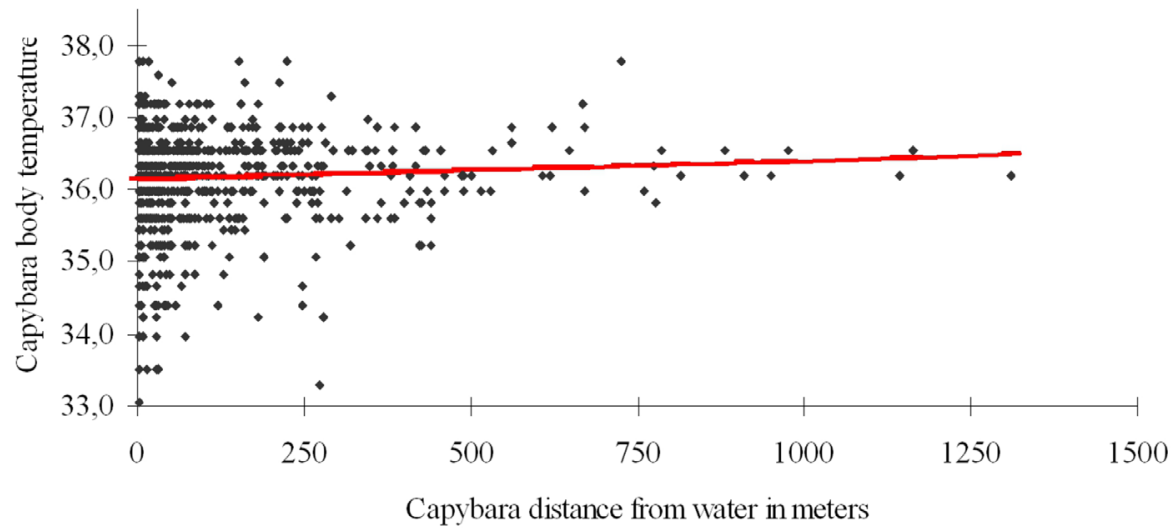

Figure 4. A) Scatterplot and linear regression of ambient temperature vs. capybara distance from water $(y=29.4909$ $-0.0072(\mathrm{x}), \mathrm{R}^{2}=$ $0.02, P<0.001) . \quad$ B) Scatterplot and linear regression of capybara body temperature vs. distance from water $(\mathrm{y}=$ $36.1138+0.003(\mathrm{x}), \mathrm{R}^{2}$ $=0.004, P=0.02$ )

The overall average estimated 95\% Kernels of 183 ha were similar to the estimates of home range for populations of capybara in the Brazilian Pantanal, with ranges of 200 ha (Schaller and Crawshaw 1981) and 196 ha (Alho et al. 1987, 1989). These home range sizes were considerably larger than those found in Venezuela by Herrera and Macdonald (1987) with home ranges of 10 to 16 ha with much higher population densities. Smaller home ranges and higher densities in the Ilanos of Venezuela could be due to the higher productivity of the grasslands than in the Pantanal or the Gran Chaco (Herrera and Macdonald 1989). 
In general, capybaras were found close to man made ponds. In the Gran Chaco, capybara presence and survival directly depends on the availability of permanent water sources and introduced pastureland (Campos-Krauer and Wisely 2011). Natural permanent water sources in the region are scarce, and the great majority dry out during the dry season. Man made ponds are reliable year round sources of water that are regularly distributed throughout pasturelands. As a result, capybara home ranges in the central dry Chaco include two or three ponds separated by approximately $1 \mathrm{~km}$, that are typically used by multiple groups, but only by one group at any given time. Despite the considerable distance covered by capybara, $95 \%$ of all location points were $<500 \mathrm{~m}$ from a permanent water source demonstrating the importance of these ponds for capybara. A tight association with water is in agreement with previous reports (Barreto and Herrera 1998; Azcarate 1980; Cordero and Ojasti 1981; Murphey et al. 1985; Mones and Ojasti 1986; Herrera and Mcdonals 1989; Lord 1991; Quintana and Malvarez 1994, 1998). Although we found no significant difference between wet and dry season home ranges when we considered all animals, two capybaras which were members of a group of six had larger home ranges during the dry season than during the wet season. Expansion during the dry season could be due to a need for additional food resources to support the group as productivity declined during the dry season. The dry season home ranges of solitary or paired capybaras were smaller than those of a larger group.

Considering that the capybara is a semi-aquatic rodent, it was not unexpected that open water surface was a preferred habitat type. Also preferred, however, was the Chaco forest. Chaco forest surrounded the great majority of ponds in the study area; we believe that the dense vegetation of the forest plays a significant role for capybara survival in the region. The forest likely serves as a cool shaded area during the hot summer and provides shelter from the cold south winds during winter, as well as suitable protection from predators. Introduced pastureland was also greatly preferentially used, providing extensive high quality forage year round for capybaras. Without pasturelands, capybara foraging habitat would be confined to small, periodically flooded natural pasture, or the vegetation immediately surrounding man made ponds. Interestingly, capybaras avoided shrub Chaco forest. The lack of understory vegetation provided few food resources and little protection against extreme climatic conditions and predators, making this habitat risky for capybaras.

Average body temperature of capybaras in our study $\left(36.15^{\circ} \mathrm{C}\right)$ was similar to body temperatures (36.0 to $36.6{ }^{\circ} \mathrm{C}$ ) found by López-Barbella (1982). Body temperature was positively correlated with distance from water. These findings suggest that capybaras use water to thermoregulate as well as for predator avoidance. Our interpretation is further supported by the fact that capybaras ventured further away from water only when ambient temperatures were low (Fig. 4A, B). Although capybaras have been anecdotally reported to use water for thermoregulation, this is the first study providing evidence for this phenomenon through the use of internal temperature sensors. Other semi aquatic rodents such as the European beaver (Castor fiber), American beaver (Castor canadensis), and the Australian water rat (Hydromys chysogaster) also use water as a thermoregulatory tool and have developed physiological adaptations to optimize the benefits of water high cooling capacity (Steen and Steen 1965; Hart 1971; Fanning and Dawson 1980). 
Similarly, the capybara has evolved skin and hair that enhances the ability of water to regulate body temperature. Capybara epidermis is covered in folds of tissue which creates a larger surface area; additionally, the hair emerges at an acute angle and is clumped in groups of three or four follicles with the clumps spaced relatively sparsely which speeds the drying and body cooling process consequently reducing the body temperature (Pereira et al. 1980).

A

\begin{tabular}{lcccccc}
\hline & Open water & $\begin{array}{c}\text { Flooded grass } \\
\text { area }\end{array}$ & Pasture & Shrub forest & Chaco forest & Rank \\
\hline Open water & & - & -- & + & -- & 1 \\
Flooded grass area & + & - & - & + & - & 2 \\
Pasture & +++ & + & --- & & -- & 3 \\
Shrub forest & - & - & + & -+ & 0 \\
Chaco forest & +++ & + & +++ & +++ & & 4 \\
\hline
\end{tabular}

$\mathrm{ChF}>\mathrm{P}>\mathrm{FGA}>\mathrm{W}>\mathrm{ShF}$

B

\begin{tabular}{lcccccc}
\hline & Open water & $\begin{array}{c}\text { Flooded grass } \\
\text { area }\end{array}$ & Pasture & Shrub forest & Chaco forest & Rank \\
\hline Open water & +++ & +++ & +++ & +++ & 4 \\
Flooded grass area & -- & - & + & - & 1 \\
Pasture & --- & + & + & & - & 2 \\
Shrub forest & --- & - & -- & & -- & 0 \\
Chaco forest & --- & + & + & +++ & & 3 \\
\hline
\end{tabular}

$\mathrm{W}>\mathrm{ChF}>\mathrm{P}>\mathrm{FGA}>\mathrm{ShF}$
Table 4. A. Ranking matrices for the overall comparison of habitat type use from minimum convex polygon home range versus habitat availability in the entire study area. B. Ranking matrices for capybara based on comparing proportion of radio locations for each animal in each habitat type within MCP home ranges per season. Each average element in the matrix was replaced by its sign. Sing represents level of significant deviation from random at $P<0.05$. A value of 4 corresponds to the highest significantly used habitat, a value of 0 correspond to the lowest significant used habitat type.

Worldwide, anthropogenic land use change and fragmentation are implicated in the establishment of invasive species and expansion of native ones (Lockwood et al. 2007; Peterson and Vieglais 2001). Capybaras expanded their range to the Central Dry Chaco after large-scale deforestation occurred for ranching (Campos-Krauer and Wisely 2011).

It appears that ample forage and suitable cover were created when Chaco forest was fragmented. Perhaps more important to the expansion of capybaras into this region was the creation of regularly distributed, permanent water sources in this otherwise xeric habitat. As a taxon, rodents are highly successful invaders. They exhibit demographic traits necessary for expansion and invasion such as high fecundity, short generation time and opportunistic breeding which can provide advantages over local fauna. Rodents cause losses to harvest and can serve as vectors and host for diseases, and are the most significant crop pests (Singleton et al. 1999, Chu et al. 2003). Where they have invaded they often further alter habitat, examples being the American beaver (Castor canadensis; Fasanella et al. 2010) and the coypu (Myocastor coypus; Guichon et al. 2003). With 
voracious appetites and high reproductive rates, these species are of great concern world wide.

The capybara also appears to be a species capable of taking advantage of anthropogenic land management and transformation. Large scale land cover change from Chaco forest to a patchwork of pasture and forest appears to be a critical factor allowing the capybara to expand its distribution to these regions. The central dry Chaco region has been intensively transformed during the last 70 years. This habitat transformation has drastically changed the structure and distribution of Chaco forest, creating conditions which have allowed the capybara to expand its range into an area previously inhospitable to it. Establishment in this region, however, is driven by the artificial provision of water.

The expansion of the capybara into the central dry Chaco is a clear consequence of the great land transformation that is affecting the area and its appearance should alert those responsible that the Gran Chaco ecosystem is being irreparably altered. Expanding species can outcompete native species and alter ecosystem services. Indeed, the presence of capybaras in the central Chaco may already be altering the epizootiological landscape of the region. Capybaras are reservoir hosts of Trypanosoma evansi, a protozoan parasitic infection that infects both domestic and wild mammals (Franke et al. 1994). At present, capybara population numbers are still small and have not been linked to any agricultural damage or disease reservoir in the central dry Chaco, but as livestock and capybara densities increase in this region (Campos-Krauer and Wisely 2011), the potential for disease outbreak will also augment. This study increases our understanding of the extent of the spatial distribution and ecological requirements of capybara which will be essential for effective management of this newly established species.

\section{Acknowledgments}

Special thanks to the owners of Estancia Edito for their immense hospitality and for allowing us access to their land. Thanks to E. Gomez for her valuable help and support from the Secretaria del Medio Ambiente, Paraguay (SEAM). Special thanks to D. Meritt and R. Klemm for their support and guide. Thank you to the three anonymous reviewers for their insightful comments. Financial support for this study came from a Fulbright Scholarship to JMCK, Academic and Professional Program for the Americas (LASPAU), and the Division of Biology, Kansas State University. Logistic support came from Proyecto Taguá, Toledo, Paraguay. All collecting was carried out under Paraguay permit numbers 1/05, 1/06, 1/07, RNVS 0183 under KSU Institutional Animal Care and Use Committee protocol number 2362 .

\section{References}

Acevedo, P., M. A. Escudero, R. Munoz, and C. Gortazar. 2006. Factors affecting wild boar abundance across an environmental gradient in Spain. Acta Theriologica 51:327-336.

Adámoli, J., E. Sennhauser, J. Acero, and Rescia, A. 1990. Stress and disturbance: Vegetation dynamics in the dry Chaco region of Argentina. Journal of Biogeography 17:491500.

Aebischer, N. J., P. A. robertson, and R. E. Kenward. 1993. Compositional analysis of habitat use from animal radiotracking data. Ecology 74:1313-1325. 
Aguirre, A. A., and G. M. Tabor. 2008. Global Factors Driving Emerging Infectious Diseases Impact on Wildlife Populations. Animal Biodiversity and Emerging Diseases: Prediction and Prevention 1149:1-3.

Atho, C. J. R., Z. M. Campos, and H. C. Goncalves. 1987. Ecologia de capivara (Hydrochoerus hydrochaeris, Rodentia) do Pantanal: I. Habitats, densidades e tamanho de grupo. Revista Brasileira de Biologia 47:88-97.

AzCarate, T. 1980. Sociobiología y manejo del capibara (Hydrochoerus hydrochaeris). Doñana Acta Vertebrata 7:1-228.

Barreto, G. R., and E. A. Herrera. 1998. Foraging patterns of capybara in a seasonally flooded savanna of Venezuela. Journal of Tropical Ecology 14:87-98.

BenirsChKe, K., M. L. Byrd, AND R. J. Lowe. 1989. The Chaco region of Paraguay: peccaries and Mennonites. Interdisciplinary Scientific Review 14:144-147.

ВRоокs, D. M. 1998. Habitat variability as a predictor of rarity in large Chacoan mammals. Vida Silvestre Neotropical 7:115-120.

Caldas, M. M., D. Goodin, S. Sherwood, J. M. Campos Krauer, and S. M. Wisely. 2013. Land-cover change in the Paraguayan Chaco: 2000-2011. Journal of Land Use Science 8:1-18.

Campos-Krauer, J. M., and S. M. Wisely. 2011. Deforestation and cattle ranching drive rapid range expansion of capybara in the Gran Chaco ecosystem. Global Change Biology 17:206-218.

Cordero, G. A., AND J. OJastı. 1977. Comparative study of capybara populations (Hydrochoerus hydrochaeris) of forest and savannah. Acta Científica Venezolana 28:42-42.

Cordero, G. A., AND J. OJastı. 1981. Comparison of Capybara Populations of Open and Forested Habitats. Journal of Wildlife Management 45:267-271.

Chu, Y. K., R. D. Owen, L. M. Gonzalez, and C. B. Jonsson. 2003. The complex ecology of hantavirus in Paraguay. The American Journal of Tropical Medicine and Hygiene 69:263-268.

EIDT, R. C. 1968. The climatology of South America. Biogeography and ecology of South America. Monographiae Biologicae 18:54-81.

FAHRIG, L. 2003. Effects of habitat fragmentation on biodiversity. Annual Review of Ecology and Systematics 34:487-515.

Fanning, F. D., AND T. J. Dawson. 1980. Body Temperature Variability in the Australian Water Rat, Hydromys chrysogaster, in Air and Water. Australian Journal of Zoology 28:229-238.

Fasanella, M., S. Poljak, and M. S. Lizarralde. 2010. Invasive North American Beaver (Castor canadensis): The Distribution of Mitochondrial Variation Across the Archipelago of Tierra del Fuego. Mastozoología Neotropical 17:43-52.

Fener, H. M., J. R. Ginsberg, E. W. Sanderson, and M. E. Gompper. 2005. Chronology of Range Expansion of the Coyote, Canis latrans, in New York. Canadian Field Naturalist 119:1-5.

Franke, C. R., M. Greiner, and D. Mehlitz. 1994. Investigations on Naturally-Occurring Trypanosoma Evansi Infections in Horses, Cattle, Dogs and Capybara (HydrochaerisHydrochaeris) in Pantanal de Pocone (Mato-Grosso, Brazil). Acta Tropica 58:159169. 
Gannon, W. L., R. S. Sikes, and the Animal Care and Use Committee of The American Society of Mammalogists. 2007. Guidelines of the American Society of Mammalogists for the use of wild mammals in research. Journal of Mammalogy 88:809-823.

Glatzle, A. 1999. Compendio para el Manejo de Pasturas en el Chaco. Edición El Lector. Asunción, Paraguay.

Gonzalez, E., ANd R. Parra. 1972. Digestive Physiology of Capybara (Hydrochoerus Hydrochaeris). 2. Kinetics of Nutrients in Digestive Tract. Acta Científica Venezolana 23:28-\&.

Gorнam, J. R. 1973. The Paraguayan Chaco and its rainfall, Paraguay: ecological essays. Gainesville, Florida, Academy of Art and Science. Scientific America 4:39-60.

Guichón, M. L., C. P. Doncaster., and Cassini, M. H. 2003. Population structure of coypus (Myocastor coypus) in their region of origin and comparison with introduced populations. Journal of Zoology 3:261-265.

Hart, J. S. 1971. Rodents. pp. 1-149 in Comparative Physiology of Thermoregulation, volumen 111. Mammals (Whittow, G. C.. ed.). Academic Press. New York, EE.UU.

Herrera, E. A. 1992. Growth and Dispersal of Capybaras (Hydrochaeris hydrochaeris) in the Llanos of Venezuela. Journal of Zoology 228:307-316.

Herrera, E. A., and D. W. Macdonald. 1989. Resource Utilization and Territoriality in Group-Living Capybaras (Hydrochoerus hydrochaeris). Journal of Animal Ecology 58:667-679.

Holdridge, L. R. 1969. Estudio Ecológico del los Bosques de la Región Oriental del Paraguay. Organización de la Naciones Unidas para la Agricultura y la Alimentación FAO: SF/PAR 15.

Huang, C., S. Kim, K. Song, J. Townshend, P. Davis, A. Altstatt, O. Rodas, A. Yanosky, R. Clay, and C. Tucker. 2009. Assessment of Paraguay's forest cover change using Landsat observations. Global and Planetary Change 67:1-12.

Hueck, K. 1966. Die Wälder Südamerikas. Ökologie, Zusammensetzung und wirtschaftliche Bedeutung. Vegetationsmonographien der einzelnen Grossräume, Stuttgart, G Fischer Verlag: 422.

Kreeger, T. J., J. M. Arnemo, and J. P. RaAth. 2002. Handbook of Chemical Immobilization. International Edition. Published by Wildlife Pharmaceuticals, inc. Fort Collins, EE.UU.

LeNth, R.V. 1981. On finding the source of a signal. Technometrics 23:149-154.

LOAS $^{\mathrm{TM}}$. 2005. Ecological Software Solutions LLC. Hegymagas, Hungary. Version 4.0.2.2.

Lockwood, J. L., M. F. Hoopes, and M. P. Marchettı. 2007. Invasion Ecology. Blackwell Publishing. Oxford, United Kindom.

LoRD, R. D. 1991. 24-Hour Activity and Coprophagy by Capybaras (Hydrochaeris hydrochaeris). Studies on Neotropical Fauna and Environment 26:113-120.

LoRD, R. D. 2009. Capybaras: a Natural History of the Worlds Largest Rodent. Johns Hopkins University Press. Baltimore, USA.

Lord, R. D., AND V. R. LoRD. 1988. Cross Checking Censuses and a Model of the Annual Cycle of Mortality and Reproduction in Capybaras (Hydrochaeris hydrochaeris). Studies on Neotropical Fauna and Environment 23:213-224. 
López-Barbella, S. 1982. Una contribucion al estudio de la fisiologia reproductiva del chiguire (Hydrochoerus hydrochaeris) en cautiverio. 1. Ciclo estral. Acta Científica Venezolana 33:487-501

Macdonald, D. W. 1981. Feeding Associations between Capybaras Hydrochoerus hydrochaeris and Some Bird Species. Ibis 123:364-366.

Монr, C. O. 1947. Table of equivalent populations of North American small mammals. American Midland Naturalist 37:223-249.

Mones, A., AND J. OJastı. 1986. Hydrochoerus hydrochaeris. Mammalian Species 264:17.

Mereles, M. F. 2013. Acerca de las Extenciones de Cerrados y Cerradones en el Paraguay. Paraquaria Natural 1:63-38.

Murphey, R. M., J. S. Mariano, and F. A. M. Duarte. 1985. Behavioral Observations in a Capybara Colony (Hydrochoerus hydrochaeris). Applied Animal Behavior Science 14:89-98.

National Research Council. 2001. Grand Challenges in Environmental Sciences. The National Academies Press. Washington, USA.

NowaK, R. M. 1991. Walker's Mammals of the World. Quinta edicion. Johns Hopkins University Press. Baltimore, USA.

OJASTI, J. 1971. El Chigüire. Defensa de la Naturaleza 3:1-25.

OJASTI, J., AND Robinson. 1991. Human exploitation of capybara. Neotropical wildlife use and conservation. University of Chicago Press. Chicago, USA.

Paschoaletto, K., M. Ferraz, M. Lechevalier, M, Zarate Do Couto, and H. Martins. 2003. Damage caused by capybaras in a corn field. Scientia Agricolas 60:191-194.

Pereira, J. N., D. M. Jenkinson, and E. Finley. 1980. The structure of the skin of the capybara. Acta Científica Venezolana 31:361-364.

Peterson, A. T., and D. A. Vieglais. 2001. Predicting species invasions using ecological niche modeling: new approaches from bioinformatics attack a pressing problem. BioScience 51:363-371.

QuintanA, R. D. 2002. Influence of livestock grazing on the capybara's trophic niche and forage preferences. Acta Theriologica 47:175-183.

Quintana, R. D. 2003. Seasonal effects on overlap trophic niche between capybara (Hydrochaeris hydrochaeris) and livestock, and on trophic niche breadths in a rangeland of Central Entre Rios, Argentina. Mammalia 67:33-40.

Quintana, R. D. M., AND S. Malvarez. 1994. Feeding-Habits of Capybara (Hydrochaeris hydrochaeris) in Afforestation Areas of the Lower Delta of the Paraná River, Argentina. Mammalia 58:569-580.

Quintana, R. D. M., AND S. Malvarez. 1998a. Feeding patterns of capybara Hydrochaeris hydrochaeris (Rodentia, Hydrochaeridae) and cattle in the non-insular area of the lower Delta of the Paraná River, Argentina. Mammalia 62:37-52.

Redford, K. H., A. Taber, and J. A. Simonetti. 1990. Biodiversity: there is more to biodiversity than the tropical rain forest. Conservation Biology 4: 328-330.

Schaller, G. B. 1976. The mouse that barks. Internal Wildlife 6:12-16.

Schaller, G. B., and P. G. Crawshaw. 1981. Social organization in a capybara population. Sougetierk Mitt 29:3-16. 
Singleton, G., Hinds, L., Leirs, H., AND Z. B. Zhang. 1999. Ecologically-Based Management of Rodent Pests. Australian Centre for International Agricultural Research. Canberra, Australia.

Steen, I., AND J. B. Steen. 1965. Thermoregulatory importance of the beaver's tail, Compared. Biochemic and Physiology 15:267-70.

Steven, A., C. A. Ramotnik, and C. G. Schmitt. 2004. Collared peccary range expansion in northwestern New Mexico. Southwestern Naturalist 49:524-528.

Vitousek, P. M., A. M. Harold, J. Lubchenco, ANd J. M. Melillo. 1997. Human domination of Earth's ecosystems. Science 277:494-499.

White, G. C., and R. A. Garrott. 1990. Analysis of wildlife radio-tracking data. Academic Press, New York.

Worton, B. J. 1989. Kernel methods for estimating the utilization distribution in homerange studies. Ecology 70:164-168.

ZaR, J. H. 1996. Biostatistical analysis. Tercera edición. Prentice Hall, Inc. Upper Saddle River, USA.

Sometido: 3 de enero de 2014

Revisado: 1 de abril de 2014

Aceptado: 8 de abril de 2014

Editor asociado: Robert Owen

Diseño gráfico editorial: Gerardo Hernández 
